\title{
Pedagoogiliste arendusuuringute suunad
}

\author{
Hannu L. T. Heikkinen ${ }^{\text {al }}$ \\ ${ }^{a}$ Finnish Institute for Educational Research, University of Jyväskylä
}

\begin{abstract}
Annotatsioon
Artikli eesmärk on tutvustada õpetamise täiustamise võimalusi, milles kombineeritakse tegevõpetajate kutsetööd teadusuuringutega. Ajalooliselt on tegevusuuring, mida hakati rakendama 1940. aastatel, neist uurimisviisidest kõige vanem. Pärast seda on välja pakutud mitmeid raamistikke, mis ühendavad praktilise õpetamistegevuse akadeemiliste püüdlustega, nt arendusuuring, translatiivne uuring, tööviise arendav uuring ja praktikute teadusuuringud ning nende arvukad versioonid ja kombinatsioonid. Selle artikli teine eesmärk on uurida filosoofilisest ja teoreetilisest vaatenurgast uurimistöö teoreetiliste ja praktiliste eesmärkide seost, ühendades Aristotelese klassikalised seisukohad epistemoloogia kohta Jürgen Habermasi teadmiste ja inimlike huvide teooriaga. Metodoloogiana kasutatakse teaduskirjanduse teoreetilist ja filosoofilist analüüsi.
\end{abstract}

Võtmesõnad: tegevusuuring, pedagoogika areng, teadmised ja inimlikud huvid, Aristoteles, teadmiste sotsioloogia

\section{Sissejuhatus: pedagoogiliste uuringute suunad}

Selles Eesti Haridusteaduste Ajakirja numbris tutvustatakse akadeemilisi uuringuid, mida ühendab huvi arendada õpetamist ja õppimist ülikoolides ja koolides ehk huvi uurida ainedidaktika arendamise viise. Artiklid hõlmavad paljusid didaktilisi uuendusi, mis on seotud õppematerjalide, tehnoloogia, õppevormide ning ülikoolide ja koolide koostööga, seejuures kirjeldavad kooli- ja ülikooliõpetajad oma õpetamistavade arengut, eriti õppimiskeskse käsitlusviisi seisukohalt. Sellesse erinumbrisse kutsuti esitama kaastöid, mis on seotud õpetamis- ja õppimisalaste teadmiste paradigmaga, mida määratletakse sageli kui õpilaste õppimisviiside süstemaatilist uurimist, mis tulemuste

P.O. Box 35, FI-40014 University of Jyväskylä, Jyväskylä, Finland; hannu.l.t.heikkinen@jyu.fi 
avalikustamise kaudu edendab õpetamistavasid ja mida sageli peetakse väga lähedalt seotuks tegevusuuringute (action research) traditsiooniga.

Erinumbri autorite ühine eesmärk on uurida pedagoogiliste tavade täiustamise viise, mille abil edendada õpetamist. Samas kirjeldatakse neid viise mitmekesisel moel ja paljudest vaatenurkadest. Mõnes artiklis on sõnaselgelt nimetatud tegevusuuringuid. Teistes ei mainita tegevusuuringuid üldse ning autorid kirjeldavad oppetamise arendamist ja didaktika rakendamist koolis täiesti eri viisil.

Kuidas peaksime sellisel juhul määratlema metoodikat, mille peamine eesmärk on õpetamistavade arendamine teadustöö kaudu, st õpetamise täiustamine paralleelselt selle uurimisega? Loomulikult ei saa olemas olla vaid üht õiget käsitlust ega definitsiooni. Tänapäeval on sobiva raamistiku valimiseks eri võimalusi, nt teadus- ja arendustegevus (research and development work), tegevusuuringud (action research), translatiivsed uuringud (translational research), tööviise arendavad uuringud (developmental work research) või praktikute teadusuuringud (practitioner research), mida täiendavad nende arvukad edasiarendused. Seega, õpetamistavade arendamiseks on olemas hulgaliselt meetodeid, kuid kõiki neid seob eesmärk luua toimiv seos teooria ja praktika vahel ning arendada õpetamistavasid uurimistöö kaudu.

Artikli esimene eesmärk on anda ülevaade pedagoogiliste arendusuuringute suundadest ja selgitada välja nendevahelised seosed. Neid suundi võib pidada akadeemiliste vaadete või teoreetiliste suundade kogumiks, millest lähtudes saab teha pedagoogilist arendustööd. Artikli teine eesmärk on uurida teadusuuringute teoreetiliste ja praktiliste eesmärkide vahelist seost filosoofilisest ja teoreetilisest vaatenurgast, rakendades laiahaardelist käsitlusviisi, milles on ühendatud Aristotelese tuntud klassikaline töö inimese kaasasündinud teadmisjanu kohta saksa filosoofi Jürgen Habermasi teooriaga teadmistest ja inimlikest huvidest. Sellest lähtudes proovitakse kirjeldada teaduspõhise pedagoogilise arendustöö eri suundi. Artikli uurimismetoodikana on kasutatud tänapäevase teaduskirjanduse teoreetilist ja filosoofilist analüüsi.

\section{Valik kontseptsioone õpetamise arendamiseks}

Kõigepealt esitame kaalumiseks põhiküsimused: kuidas luua kontseptuaalne raamistik teadustegevusele, mille eesmärk on parandada õpetamisviise? Kuidas kõige paremini mõista ja analüüsida, mida me tegelikult teeme? Kuidas räk̈kida oma lugu teistele, kui me arendame oma pedagoogilisi tavasid, uurides neid samal ajal teaduslikult? Haridus- ja sotsiaaluuringute valdkonnas on neile küsimustele vastatud mitmel viisil ja neid teemasid on käsitletud 
valdkonna traditsioonide kohaselt. Võib-olla on kõige lihtsam viis anda oma tavade täiustamisest teada teadusuuringute kaudu, rääkides sellest kui teadusja arendustegevusest.

Teadus- ja arendustegevuse kontseptsioon võeti kõigepealt kasutusele tehnoloogias ja tööstuses, et arendada neis valdkondades uusi tooteid ja tootmismeetodeid. Mõistet on nüüdseks laiendatud ja tänapäeval viitab see ka üldisemalt ettevõtete või valitsuste tegevusele, millega arendatakse mitte üksnes uuenduslikke tooteid või tootmismeetodeid, vaid ka uuenduslikke teenuseid ja sotsiaalseid tavasid ning täiustatakse olemasolevaid. Arendusuuringud (design research) on teadus- ja arendustegevusega lähedalt seotud ning välja kasvanud samuti tehnoloogia ja tootmise valdkonnast. Arendusuuringud võeti alguses kasutusele projekteerimisprotsessi uuringuna, kuid metoodikat on aja jooksul laiendatud, et hõlmata projekteerimise jaoks vajalikke teadusuuringuid, st teaduspõhist projekteerimispraktikat. Samuti piirdus arendusuuringute fookus esialgu toodete ja teenuste kavandamise protsessiga, kuid nüüdseks on see laienenud ka toote ja tootmise hindamisele (van den Akker, Gravemeijer, McKenney, \& Nieveen, 2006).

Ühesuguse ülesehitusega, kuid erinevad uurimismeetodid on sageli koondatud praktikute teadusuuringute suuna alla, kuigi kõik arendusuuringute pooldajad ei aktsepteeri seda tõlgendust. Hiljuti on ka meditsiinilistel ja rahvaterviseuuringutel põhinevate translatiivsete uuringute raames võetud suund pedagoogiliste tavade väljatöötamisele tihedas koostöös praktikutega. Mõiste translatiivne uuring tähendabki teadusuuringut, mille korral teisendatakse või kantakse teadusuuringud üle praktikasse ja täiustatakse tavasid koostöös praktikutega. Teisalt viitab translatiivne uuring ka vajadusele sõnastada (n-ö tõlkida) praegused tavad teadusuuringute keelde (nt Tierney et al., 2007).

Eespool nimetatud metoodika ja juhtumiuuringute metoodika (case study methodology) vahel on samuti tihe seos. Seda metoodikat ei kasutata üksnes haridusuuringute puhul, sest juhtumiuuringuid on rakendatud eri valdkondades, nagu antropoloogia, meditsiin, psühholoogia, poliitikateadus, sotsioloogia, juhtimine, coaching, haridus, avalik haldus ning sotsiaalteenused. Lisaks tugineb tööviise arendavate uuringute koolkond (developmental work research) (Engeström \& Rückriem, 2005) ehk sekkumist pooldav uurimisviis arengupsühholoogide Võgotski ja Leontjevi sõnastatud kultuurilis-ajaloolise tegevuse teooria põhimõtetele.

Nagu eelmainitud metoodilisi suundi, saab ka arendustöö uuringuid kasutada metoodilise raamistikuna, mis võimaldab teadustöö abil muuta töökoht innovaatilisemaks, sealhulgas haridusvaldkonnas. Siiski on kõigi eelnimetatud uurimisviiside puhul tavaline, et mitmed nende pooldajad vaidlustavad teravalt igasuguse sarnasuse teiste uurimisviisidega ja teevad kõik selleks, et rõhutada 
enda oma erilisust (Heikkinen, Huttunen, \& Syrjälä, 2007; Heikkinen, de Jong, \& Vanderlinde, 2016; Välimaa, Heikkinen, \& Arvaja, 2018).

Vanim ja ilmselt kõige paremini tuntud viis teadus- ja arendustegevuse vaheliste seoste mõtestamiseks sotsiaal- ja haridusvaldkonnas on tegevusuuringud, mida sotsiaalpsühholoog Kurt Lewin tutvustas 1940. aastate lõpus USAs. Tegevusuuringuid on eri teadusvaldkondades rakendatud väga erinevas vormis rohkem kui 70 aastat. See uuringuvorm on olnud ka haridusvaldkonnas väga mõjukas. Siin on tegevusuuringuid peetud sisuliselt strateegiaks, mis ühendab õpetamise teadusuuringutega, et lahendada vahetuid probleeme protsessis osalejate refleksiooni kaudu. Ka nüüdisaegses teaduskirjanduses on tegevusuuringutele antud kindel sotsiaalne tähendus, sest need avaldavad töökollektiivile tugevat mõju. Seetõttu teevad tegevusuuringuid tavaliselt üksikisikud, kes tegutsevad meeskonna osana koos teistega või osalevad n-ö praktikute kollektiivis eesmärgiga tegeleda probleemidega ja leida neile lahendus. Sel põhjusel on tegevusuuringuid käsitlevas teaduskirjanduses sageli esile tõstetud ka professionaalseid õpikogukondi (Burns, 2007; Carr \& Kemmis, 1986; Heikkinen et al., 2007; Heikkinen, Kiilakoski, Huttunen, Kaukko, \& Kemmis, 2018; Reason \& Bradbury, 2007).

Uurimisviisi, mille puhul arendavad praktikud ise oma tööd, on kirjeldatud ka praktikute teadusuuringu (practitioner research) kontseptsioonina, mida võib pidada väga lähedaseks tegevusuuringutele, nii et mõnikord on neid termineid kasutatud lausa sünonüümidena (Heikkinen et al., 2016; Heikkinen et al., 2007). Üldiselt on praktikute teadusuuringuid määratletud kui „teadlikku ja süstemaatilist oma praktika uurimist“ (Dinkelman, 2003, lk 8). See aitab kaasa õpetamise ja õppimisega seotud lokaalsete ja konkreetsete teadmiste loomisele, samuti avalike ja üldistavate akadeemiliste teadmiste tekkele. Praktikute teadusuuringud ise moodustavad omaette teadusuuringute vormi, mis hõlmab praktikale orienteeritud uuringuid (practice-oriented research), praktikat kui uuringut (practice-as-research), praktikal põhinevaid uuringuid (practice-based research), praktikast juhitud uuringuid (practice-led research), kombineeritud teaduspraktikat (mixed-mode research practice) ja praktikat uuringu kaudu (practice through research) (Candy, 2006). Seega näib, et hoolimata ühistest juurtest ei ole praktikute teadusuuringud ühtne tervik, vaid need hõlmavad mitmeid uurimisviise. Tegelikult tundub hiljutiste kirjandusülevaadete põhjal (Broekkamp \& van Hout-Wolters, 2007; Vanderlinde \& van Braak, 2010), et termini praktikute teadusuuringud tähenduse suhtes puudub tegelik üksmeel. Isegi selle valdkonna spetsialistide hulgas näib olevat lahkarvamusi. Näiteks väidavad mõned autorid, et praktikute teadusuuringuid teevad praktikud ise, samas kui teised on arvamusel, et praktikute uuringuid saavad teha ka täistööajaga akadeemilised töötajad (Marshall, 2010). Lisaks peetakse mõnikord 
selliste uuringute peamiseks valdkonnaks kunsti, käsitööd ja disaini, samas kui mõned teadlased väidavad, et praktikute teadusuuringud kuuluvad tavaliselt haridus- ning sotsiaal- ja tervishoiuvaldkonda. Vahel julgustatakse praktikuid rohkem teadusartikleid "tarbima“ (Marshall, 2010), samas rõhutavad teised teadlased praktikute tugevat autonoomset panust teadmiste loomisse ja kõnelevad „uurimisreisist” (Loughran, 2004) või praktilise tarkuse suurendamisest ja arendamisest koosloome kaudu (de Jong, de Beus, Richardson, \& Ruijters, 2013). Praktiku tegevuse olulisust teadmiste loomises rõhutatakse eriti kriitiliste ja osalusuuringute traditsioonis (Carr \& Kemmis, 1986; Heikkinen et al., 2007; Heikkinen et al., 2016; Kemmis \& McTaggart, 2000).

Praktikute teadusuuringut kui uurimisviisi on nimetatud ka praktikal põhinevaks uuringuks (practice-based research), kuigi seda mõistet on kunsti, käsitöö ja disaini valdkonnas kasutatud konkreetses tähenduses: praktikal põhinev uuring viitab sellisele uuringule, mis on tehtud uute teadmiste saamiseks, esitades kunsti ja käsitööna valminud loomingut, sageli kontseptuaalsete teoste kujul, nagu pildid, muusika, kujundus, mudelid ja digitaalmeedia või muu looming, näiteks etendused ja näitused (Bereiter, 2002; Popper, 1963). Toodete olulisust ja nende konteksti kirjeldatakse aga verbaalselt (Candy, 2006). Teine sama tü̈pi uurimisviis on praktikast juhitud uuring (practice-led research), mis sarnaneb rohkem traditsiooniliste uurimismeetoditega, kuna rõhuasetus on teadmiste omandamisel selge eesmärgiga tegevust parandada, selle asemel et teoseid luua ja nende üle mõtiskleda. Sellised teadusuuringud hõlmavad erialast praktikat kui teadusprojekti lahutamatut osa ning kuuluvad sageli tegevusuuringute üldvaldkonna alla (Candy, 2006).

Kõiki eespool nimetatud uurimisviise seob ühine eesmärk vähendada nii palju kui võimalik erinevust teooria ja praktika vahel. Teoreetilise teadmise ning empiirilise ja praktilise oskusteabe suhe on üks kõige intrigeerivamaid probleeme, millega nende uurimisviiside korral kokku puututakse. Vastupidi valitsevale uurimisparadigma ideaalile, mille kohaselt peaks püüdma saavutada universaalseid, üldistatavaid teadmisi, julgustatakse praktikuid sageli üldistatavatele teoreetilistele teadmistele keskendumise asemel tegelema oma igapäevaste praktiliste probleemidega ning sõnastama seega lokaalseid ja kontekstipõhiseid teadmisi (Marshall, 2010).

Teooria ja praktika seoseid on teadusringkondades aastakümneid pidevalt arutatud. Sageli on teoreetilisi teadmisi peetud praktilistest kogemustest eraldiseisvaks ning seda lõhet ei näi olevat lihtne ületada. Et teoreetiliste teadmiste ja praktilise töö vahelist pinget paremini mõista ning hõlbustada nende ühendamist, peame alustuseks möönma, et kõnealune pinge teooria ja praktika vahel ei ole sugugi uus nähtus, vaid seda on käsitlenud juba antiikfilosoofid. Seetõttu peaksime põhjalikumalt uurima Antiik-Kreeka filosoofiat. Eriti mõjukas 
on olnud Aristoteles, mistõttu on kasulik käsitleda tema arusaamu teadmiste vormidest. Kuna aga filosoofide arusaam maailmast enam kui kaks aastatuhandet tagasi on fundamentaalselt erinev sellest, kuidas me tänapäeval maailma mõistame, ei piisa ainuüksi antiikfilosoofiast. Seetõttu peame arvesse võtma ka mõnda tänapäevast epistemoloogiat. Selles artiklis lähtun eelkõige filosoof Jürgen Habermasi teooriast teadmiste ja inimlike huvide kohta. Põhjus, miks just see Habermasi teooria on uuringus kesksel kohal, peitub asjaolus, et Habermas kasutab Aristotelest lähtepunktina, kuid samas töötab ta epistemoloogia jaoks välja täiesti uue ja radikaalse käsitluse, mis põhineb Aristotelese klassikalisel tüpoloogial.

\section{Teooria ja praktika ebakindel suhe: Aristotelese ja Habermasi seisukohad}

Väga muljetavaldav raamistik teooria ja praktika seoste mõistmiseks tegevusuuringutes on esitatud Wilfred Carri ja Stephen Kemmise 1982. aastal avaldatud raamatus „Becoming critical“ („Kriitiliseks muutumine“). Selles tutvustavad autorid Jürgen Habermasi filosoofilisele tööle ning tema teadmiste ja inimlike huvide teooriale toetudes kolme tegevusuuringute suunda: tehnilist, praktilist ja kriitilis-emantsipatoorset. „Becoming critical“ on üks tsiteeritumaid raamatuid hariduse tegevusuuringute valdkonnas. See on olnud pidevalt trükis rohkem kui kolm aastakümmet ning Google Scholari kohaselt on seda tsiteeritud rohkem kui 14000 korda, sealhulgas hispaaniakeelset tõlget. Carr ja Kemmis on oma ideid edasi arendanud ning siinses artiklis rakendan peamiselt raamatus „Enabling praxis“ („Jõustamise praktika“) (Kemmis \& Smith, 2008a, 2008b) esitatud ideid, mis tuginevad Carri ja Kemmise 1980. aastate alguses kasutusele võetud ideede edasiarendusele ning laiendavad seda rohkem Aristotelese filosoofia suunas.

Põhiküsimused, mida iga tegevusuuringut tegev või praktikust teadlane peab kas teadlikult või alateadlikult küsima, on järgmised: mis eesmärgi ja sihiga teadmisi omandatakse või luuakse ning kuidas neid sotsiaalses läbikäimises kasutatakse? Alternatiivina võiks küsida: milliseid olemuslikult tähtsaid inimlikke ja ühiskondlikke huvisid teadmised teenivad? Et mõista, mis eesmärgil luuakse teadmisi haridusvaldkonnas ja haridusvaldkonna jaoks, on vaja alustada teadmiste põhisuundadest ning Aristotelese „Nicomacheani eetikas" (2011) esitatud teadmiste ja tegevuse seostest. Aristotelese sõnul on teadmiste suhtes kolme liiki kalduvust (epistēmē, technē ja phronèsis) ning kolm neile vastavat inimtegevuse vormi (theōria, poiēsis ja praxis). 
Aristotelese epistēmē põhineb kalduvusel otsida vaid universaalseid ja igavikulisi tõdesid, kus ideaalis nähakse maailma meie ümber nagu läbi Olümpose jumalate silmade. Seda teadmiste vormi nimetatakse tänapäeval teoreetiliseks teadmiseks ning seda peetakse puhtaks teadmiseks selles mõttes, et teadval subjektil ei ole mingeid eesmärke ega püüdlusi peale pelga teadmise, kuidas asjad on. Seega eeldatakse, et ideaalne teadlane püüdleb objektiivsete ja universaalsete teadmiste poole, mis on tõesed sõltumata ajast ja kohast. Epistēmēe kalduvusega inimtegevuse vormi nimetatakse theōria' ks (mõtisklev tegevus), mille algne kreekakeelne tähendus oli 'nägemine' või 'vaatlemine'. (Aristotle, 2011, 1139a, 27-8; Kemmis \& Smith, 2008a; Mahon, Heikkinen, \& Huttunen, 2019; Saugstad, 2005)

Kaldumist materiaalsete hüvede loomiseks vajalike teadmiste poole nimetab Aristoteles teise terminiga: technē (Aristotle, 2011, 1094a, 5-10). Technē on kalduvus teadmiste suunas, mida on vaja millegi tegemisel või tootmisel, st poiessis (valmistamine). Termin technē leiab väljendust tehniliste teadmiste ja tehnoloogiaga seotud tänapäeva mõistetes. Tehnilised teadmised ei ole iseenesest väärtuslikud, nende olulisust saab hinnata ainult toodete valmistamise ja tootmise kaudu. Need on „head“ ja kehtivad vaid siis, kui need aitavad toota kasutuskõlblikke ja sobivaid objekte või teenuseid või välja töötada meetodeid, mille abil saab neid toota. Seega on tehniliselt orienteeritud isikul kalduvus teadmistele, mis aitavad tal leida eesmärkide saavutamiseks tõhusaid vahendeid. Selles mõttes on tehnilised teadmised kasulikud: nende otstarve jääb teadmistest enestest väljapoole. (Aristotle, 2011; Kemmis \& Smith, 2008a; Mahon et al., 2019)

Kolmas Aristotelese (2011, 1140b, 1-6) eristatud kalduvus teadmistele on phronēsis. Sageli praktiliseks tarkuseks tõlgitud phronēsis on kalduvus otsida/ teada, kuidas elada koos teistega mõtestatud, õnnelikku ja väärilist elu. Phronēsis'ega seotud tegevuse vormi (tegemist) nimetatakse praxis'eks. Selline inimtegevus seisneb voorusliku elu elamises valikute ja tegude kaudu, mis põhinevad otsustustel selle kohta, mis on igapäevaste dilemmade ja olukordade lahendamisel tark ja õige. Erinevalt poiēsis'est ei saa praxis'e puhul eesmärke tegevusvahenditest eristada; praxis on iseenesest lõppeesmärk. See on möödapääsmatu element, et elada õitsvat ja väärtuslikku ehk head elu, mida antiikkreeklased nimetasid eudaimonia'ks. Aristotelesest inspireerituna on Stephen Kemmis ümber tõlgendanud ja ümber määratlenud eudaimonia põhiideed oma väljendis „elada hästi maailmas, mis väärib elamist“, milles on nii individuaalsed ja sotsiaalsed aspektid kui ka hea elu ajalisus võetud kokku ülimalt kompaktsel kujul. Praxis'e vaatenurgast on haridustavade arendamise põhieesmärk (= tegevusuuringud hariduses ja hariduse jaoks) edendada arusaamist sellest, kuidas elada head elu ning võimaldada inimestele õitsvat ja 
tähendusrikast elamist koos teisega, võttes arvesse inimeste kohta maailmaruumis. (Kemmis \& Smith, 2008a; Mahon et al., 2019)

Olgugi et analüüsi eesmärgil on eelnimetatud kolme kalduvust (epistēmē, technē ja phronēsis) ja neile vastavat kolme inimtegevuse vormi (theōria, poiēsis ja praxis) otstarbekas esitada just sellisel viisil struktureerituna, peame siiski meeles pidama, et igapäevaelus ja inimtegevuses on need kõik omavahel seotud ja aitavad kaasa heale elule. Et elada head elu, vajame võimet jälgida ja näha, mõista ja tõlgendada maailma (theōria) ning kasutada inimkonna hüvanguks (praxis) tehnoloogiat, materjale ja loodusressursse (poiessis). Ometi on see phronēsis, mis peaks suunama haridust ja hariduse arengut kõige enam, allutades teoreetilised teadmised (epistēmē) ja tehnilised teadmised (technē) praktilisele ratsionaalsusele (phronēsis). (Kemmis \& Smith, 2008a; Mahon et al., 2019)

Nendele kolmele teadmistega seotud kalduvusele võime lisada neljanda (vt Kemmis \& Smith, 2008a) - kriitilise kalduvuse -, mis põhineb Habermasi (1972) teadmistepõhistel huvidel ja tema kirjeldatud „kriitilis-emantsipatoorsel" kalduvusel. Habermasi jaoks on teadmised alati inimlike vajaduste tulem ja kunagi ei sooritata mingit puhast intellektuaalset akti, millest teadev subjekt „ei ole huvitatud“ (Carr \& Kemmis, 1986, lk 134). Ta tutvustab kriitilisemantsipatoorset huvi kui huvi teadmiste vastu, mis teenib inimeste vajadust vabaneda mis tahes sunniviisilisest, ebaseaduslikust või ideoloogilisest jõust. Sellest lähtudes eristame kriitilist kalduvust teadmistele.

Kriitiline kalduvus on dispositsioon, mis paljastab uskumuste süsteeme ja kategooriaid, millel on ebamõistlik ja allutav võim inimeste üle. Sellise paljastuse eesmärk (st kriitilise teabe genereerimine) on anda inimestele võimalus vabaneda võimumehhanismidest, mis neid rõhuvad või kahjustavad, näiteks toetades autonoomse mõtlemise ja tegutsemise võimet. Sellest vaatenurgast lähtudes paistab sotsiaalne maailm võimuvõitluse areenina. Neljanda kalduvusega seotud tegevus toimub emantsipatoorse tegevuse vormis (Habermas, 1972; Kemmis \& Smith, 2008a) või „mõjuvõimu suurendamisena“ (Heikkinen \& Huttunen, 2017). See viib „kollektiivse kriitilise mõtiskluse ja tegevuseni, mille eesmärk on ületada irratsionaalsus, ebaõiglus, kannatused, kahju, ebaproduktiivsus või jätkusuutmatus“ (Kemmis \& Smith, 2008a, lk 23). Kõnealune tegevus on „kollektiivne“ selles mõttes, et see väljendub mõtisklevas suhtlemises ja suhetes teistega. See on ka ümberkujundav, sest selle tulemusena muutuvad (ideaalis ja korraga) olud ja inimene ise. Sellist ümberkujundava tegevuse vormi võib mõista kui kriitilist praxis't, mis seob Aristotelese praxis'e marksistlike tõlgendustega praxis'est. (Carr \& Kemmis, 1986; Kemmis \& Smith, 2008a; Mahon et al., 2019) 
Tabelis on esitatud eelkirjeldatud kalduvused ja tegevusvormid, samuti nende ning praxis'e ja kriitilise praxis'e seos. Siinkohal on oluline märkida, et praxis'e ja kriitilise praxis'e vaheline eraldusjoon on hägune. Praktika kriitilist külge võib pidada praxis'e oluliseks elemendiks, mida tuntakse sotsiaalses maailmas osalustegevusena. Seda illustreerib tabelis praxis'e ja kriitilise praxis'e vaheline kriipsjoon ning nooled, mis lähendavad praxis'e ja kriitilise praxis'e teineteisele. Kriitilise praxis'e idee toob esile pedagoogika arengu seisukohalt väga erilise käsitluse, mida selgitatakse lähemalt allpool. (Kemmis \& Smith, 2008a, 2008b; Mahon et al., 2019)

Tabel. Aristotelese (2011) ja Jürgen Habermasi (1972) teadmistepõhiste tegevusvormide ja kalduvuste süntees. Muudatused lähtuvad järgmistest artiklitest: Heikkinen et al. (2018), Kemmis \& Smith (2008a, 2008b), Kemmis (2012), Kemmis \& Edwards-Groves (2017) ja Mahon et al. (2019)

\begin{tabular}{|c|c|c|c|c|}
\hline & \multicolumn{3}{|l|}{ Aristoteles } & \\
\hline & & \multicolumn{3}{|l|}{ Habermas } \\
\hline \multirow[t]{4}{*}{$\begin{array}{l}\text { Peda- } \\
\text { googilise } \\
\text { praktika } \\
\text { põhisuunad }\end{array}$} & $\begin{array}{l}\text { Teadus- } \\
\text { uuringud } \\
\text { hariduse } \\
\text { kohta }\end{array}$ & \multicolumn{3}{|c|}{ Hariduse jaoks tehtavad teadusuuringud } \\
\hline & $\begin{array}{l}\text { Teadmised } \\
\text { on ise- } \\
\text { enesest } \\
\text { väärtus- } \\
\text { likud }\end{array}$ & \multicolumn{3}{|c|}{ Teadmised on väärtuslikud pedagoogika täiustamiseks } \\
\hline & $\begin{array}{l}\text { Teoreetiline } \\
\text { Kuidas } \\
\text { asjad on? }\end{array}$ & $\begin{array}{l}\text { Tehnilised } \\
\text { vahendid } \\
\text { Kuidas luua } \\
\text { efektiivseid } \\
\text { õppe- } \\
\text { vahendeid? }\end{array}$ & $\begin{array}{l}\text { Tõlgendav- } \\
\text { praktiline } \\
\text { Kuidas mõista } \\
\text { õppimise ja } \\
\text { õpetamise prot- } \\
\text { sesse, sealhulgas } \\
\text { sotsiaalseid, } \\
\text { ajaloolisi, poliiti- } \\
\text { lisi ja ökoloogilisi } \\
\text { vaatenurki? }\end{array}$ & $\begin{array}{l}\text { Kriitilis- } \\
\text { emantsipatoorne } \\
\text { Kuidas täiustada } \\
\text { pedagoogilisi tavasid, } \\
\text { et edendada seadus- } \\
\text { likkust, õiglust ja } \\
\text { võrdsust inimeste } \\
\text { vahel, pidades sil- } \\
\text { mas globaalseid ja } \\
\text { ökoloogilisi seisukohti? }\end{array}$ \\
\hline & \begin{tabular}{|l} 
Praktilis- \\
teoreetilised \\
uurimisviisid \\
(harjutus- \\
teooriad)
\end{tabular} & \multicolumn{2}{|c|}{$\begin{array}{l}\text { Praktiku uurimisviis } \\
\text { (praktikal põhinevad teadus- } \\
\text { uuringud, praktikale orienteeri- } \\
\text { tud teadusuuringud, praktikast } \\
\text { juhitud teadusuuringud, praktikute } \\
\text { teadusuuringud jne) }\end{array}$} & $\begin{array}{l}\text { Praktilis-kriitilised } \\
\text { uurimisviisid } \\
\text { (kriitilis-emant- } \\
\text { sipatoorsed } \\
\text { tegevusuuringud, } \\
\text { osalusuuringud) }\end{array}$ \\
\hline
\end{tabular}




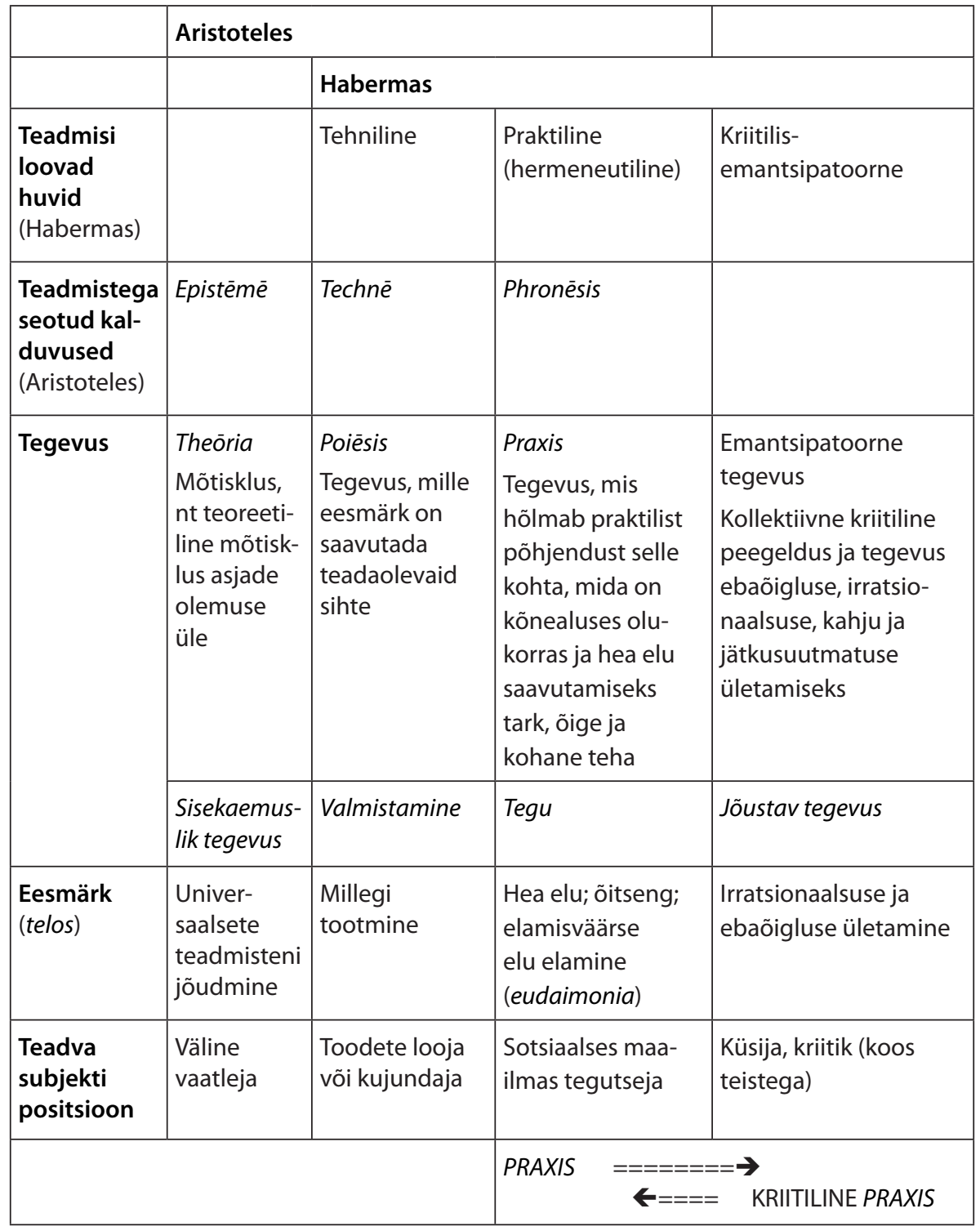

Teadustöös võime eristada nelja suunda, mis on paralleelsed nelja eespool nimetatud kalduvusega teadmistele ehk huvile teadmiste vastu. Esimene suund, mida võib nimetada teadusuuringute teoreetiliseks suunaks (theoretical orientation), on kõige lähemal traditsioonilisele empiirilis-analüütilisele uurimisparadigmale ning huvitatud peamiselt küsimusest, „kuidas on asjad maailmas seatud" ehk millised on õpetamise ja õppimise kohta käivad üldised seadused. Vaatlusalust põhisuunda võib kirjeldada kui teadusuuringuid hariduse kohta, mida võib kokkuvõtvalt nimetada ka praktilis-teoreetiliseks uurimisviisiks 
(practice-theoretical approach). Sellel haridusuuringutes endiselt kõige levinumal suunal on pedagoogilise arengusuunana üldsusele siiski vähe pakkuda. Õpetajate ja haridustöötajate jaoks on lähtepunkt tegelikult täiesti vastupidine: peamine, mida nad tahavad, on parandada oma tegevust, mitte teada rohkem üldistest seaduspärasustest või reeglitest.

Selle asemel, et teha teadusuuringuid hariduse kohta, võiks võtta seisukoha, et teadusuuringuid tuleb teha hariduse jaoks, st parandada tuleb haridustavasid, tehes uurimistööd koos haridusvaldkonnas tegutsevate inimestega. Samas võime alati küsida, kas suuremad üldteoreetilised teadmised tavade kohta (teadusuuringud hariduse kohta) ei annaks meile paremat alust nende tavade paremaks muutmiseks (teadusuuringud hariduse jaoks). Seetõttu ei ole nende kahe suuna seos mitte kas „see või teine“, vaid pigem „nii see kui ka teine“. Põhimõtteliselt võime alustada ükskõik kummast mündi küljest: võime kõigepealt tahta kas rohkem teada või tegutseda paremini.

Teadusuuringud hariduse jaoks toimuvad teadlaste ja praktikute dialoogi kaudu. See suund avaldub nii praktiku uurimisviisis (practitioner approach) kui ka praktilis-kriitilises uurimisviisis (practice-critical approach). Paljud autorid näivad arvavat, et teadusuuringuid ei saa ei hariduse kohta ega jaoks teha „väliselt positsioonilt", vaid teadlane peab olema ise haridusvaldkonnaga seotud, et mõista seda „siseringi positsioonilt“ (Anderson \& Herr, 1999). Samas muutub haridusvaldkond pidevalt. Selle jagamine objektideks, faktideks ja väideteks, mida kasutatakse ehitusplokkidena inimtekkelise maailmavaate konstrueerimisel, on kunstlik. Reaalsus on dünaamilisem ehk seosed muutuvad pidevalt. Selline arusaam vaidlustab vajaduse otsida objektiivset seisukohta, mida on rõhutatud üldistele ja objektiivsetele teadmistele orienteeritud (post)positivistlikus uurimisparadigmas, mida kohaldatakse hoolimata tegelikust ainelisest, ajaloolisest või sotsiaalsest kontekstist või teadmiste koguja isiklikest kogemustest. Kõnealust muutust võib mõista kui paradigma nihet positivismi juurest läbi postpositivismi kriitiliste teooriate, konstruktivismi ja postmodernismi poole (Denzin \& Lincoln, 2005; Heikkinen et al., 2016; Niglas, 2004).

Niisiis ei ole praegusel juhul asjakohane rääkida kalduvusest puhta teadmise poole selle enda pärast. Pigem võiksime küsida, kas on üldse võimalik luua teadmisi, mis on igapäevastest muredest eraldatud (Carr \& Kemmis, 1986, lk 134). Seega võime tahta luua kontekstipõhiseid ja lokaalseid teadmisi, mis annavad ülevaate sellest, kuidas arendada haridustavasid konkreetsetes praktilistes olukordades. Eeltoodust hoolimata on aga selge, et tavade parandamiseks on üldistatavad ja universaalsed (teoreetilised) teadmised kasulikud, sest selliste teoreetiliste teadmiste abil saab arendada lokaalseid ja kontekstipõhiseid tegevusi. Kui me võtame selle põhisuuna omaks, siis võime öelda, et me ei tee teadusuuringuid hariduse kohta, vaid pigem hariduse jaoks. 
Eelkirjeldatud põhisuund lähtub kolmest huvist. Esiteks võiksime keskenduda instrumentaal-ratsionaalsest vaatenurgast tõhusate õpetamismeetodite leidmisele. Uurimisviis, mida tähistatakse terminiga tehnilis-instrumentaalne suund (technical-instrumental orientation), rõhutabki vahendite ja eesmärkide ratsionaalset tasakaalu ning on huvitatud tõhusate õpetamis- ja õppimisvahendite ja -meetodite väljatöötamisest. Peamine eesmärk on luua meetodeid, mis mõjutavad tõhusalt õpitulemusi. Selliselt uurimisviisilt oodatakse selgeid empiirilisi tõendeid selle kohta, kuidas uued õpetamismeetodid õppimist tõhustavad, ning neid väljendatakse sageli kvantifitseeritud vormis ja saadakse võrdlusuuringute kaudu. Meetodite efektiivsust tõestatakse kausaalse loogika abil, mille korral keskendutakse põhjuste ja mõju seostele. Traditsiooniliselt on didaktilised teadus- ja arendustegevused tõukunud just sellest tehnilis-ratsionaalsest suunast.

Teiseks võiksime valida tõlgendava-praktilise (interpretive-practical) uurimisviisi. Sel juhul ei ole me huvitatud mitte niivõrd konkreetse õppemeetodi põhjustest ja mõjust, vaid me tahame pigem üldjoontes mõista õppimist ja õpetamist kui protsesse, sealhulgas nende sotsiaalseid, ajaloolisi, poliitilisi ja ökoloogilisi aspekte. Vaatlusaluse suuna puhul ei keskenduta üksnes õppimiseks ja õpetamiseks tõhusate meetodite arendamisele, vaid ka hariduse eesmärkidele ja väärtustele. Sellist suunda, mille raames huvitutakse peale vahendite ka eesmärkidest, võiks nimetada haridusuuringuks (research on education), mis võiks olla alternatiiviks õpetamistavade uuringule (research on schooling), milles kasutatakse eespool tutvustatud tehnilis-instrumentaalse suunitlusega uurimisviisi (Heikkinen et al., 2018).

Kolmandat huvi, millest lähtub pedagoogiliste tavade täiustamine, võiks nimetada pedagoogilise arendustöö kriitiliseks suunaks. Sellise uurimissuuna korral saadakse teavet kriitiliste ülevaadete kaudu ja seda kujundavad kriitilised kalduvused, mis Habermasi arvates viitavad kriitilis-emantsipatoorsele huvile teadmiste vastu. Praegusel juhul oleme huvitatud küsimusest, kuidas parandada pedagoogilisi tavasid, et edendada seaduslikkust, õiglust ja võrdsust inimeste vahel. Nagu Carr ja Kemmis (1986, lk 204) on märkinud, põhineb see suund eespool nimetatud tõlgenduslikul-praktilisel suunal, sisaldades selle suuna vorme ja ajendeid, kuid laiendab neid koostööle, mille eesmärk on muuta haridusasutusi nii, et inimestevaheline seaduslikkus, õiglus ja võrdsus oleks seal paremini tagatud, võttes sealhulgas arvesse üleilmseid ja ökoloogilisi aspekte. Kriitilis-emantsipatoorse uurimissuuna eeldus on, et teadlane ja ühiskond, milles teadustööd tehakse, on teadlikud konkreetsete ja lokaalsete pedagoogiliste tavade sotsiaalsetest, poliitilistest, ajaloolistest ja ökoloogilistest tingimustest. Teisisõnu võib tõlgenduslikku-praktilist suunda vaadelda liikumisena kriitilis-emantsipatoorse uurimisviisi poole. Seda suunda võib 
nimetada ka pedagoogilises keskkonnas rakendatavaks kriitiliseks praxis'eks. Selline pedagoogiline arendustöö on kõige sagedamini kollektiivne sotsiaalne tegevus, millega kaasnevad kriitika ja vajaduse korral iseenesestmõistetavaks muutunud diskursuste, struktuuride ja suhete ümberkujundamine, mis eeldab kindlaid haridustavasid (ja sageli ka määrab need) ning takistab tegutsemist nii hariduskeskkonnas kui ka ühiskonnas üldisemalt. Sellest vaatenurgast tähendab pedagoogiliste tavade arendamine kriitiliste suundade rakendamist ja kriitilise mõtlemise toetamist eesmärgiga saada jagu ebaõiglusest, ajupesust või ideoloogilisest töötlemisest hariduses ning lõppkokkuvõttes aidata hariduse ja teadmiste loomise kaudu kaasa õiglasema ja jätkusuutlikuma ühiskonna tekkele (Mahon et al., 2019). Kõnealust vaatepunkti hariduse arengu kohta on propageeritud eelkõige praktilis-kriitilise uurimisviisi traditsioonis ehk osalusuuringutes ehk kriitilis-emantsipatoorsetes tegevusuuringutes.

\section{Järeldused: kas lasta kõigil lilledel õitseda?}

Et leida endale sobiv viis arendada õpetamistavasid ja sellele nimi anda, on mitu võimalust. Teadmiste sotsioloogia vaatenurgast lähtudes on võimalik valida erisuguste alternatiivide vahel, kaldudes kas (teaduslike-poliitiliste) „parteide“ või „akadeemiliste hõimude“ suunas. Samas esitavad teadusuuringute traditsioonid tegelikkusele erinevaid eeldusi (ontoloogilised eeldused) ning nende arusaamad teadmistega seotud huvide ja kalduvuste kohta (epistemoloogilised eeldused) on üksteisega vastuolus.

Esiteks võime käsitleda teaduslikke uurimisviise ja paradigmasid eri sotsiaalsete kogukondade vaadetena. Teadmiste sotsioloogia traditsiooni raames uuritakse peamiselt inimese mõtte ja sotsiaalse konteksti seost, mille kaudu genereeritakse teadmisi. Vahel võib olukord sarnaneda lilleväljaga, kus lilled õitsevad harmooniliselt kõrvuti, teinekord meenutab see rohkem perekondlikku vaidlust või lahingut rivaalitsevate akadeemiliste hõimude vahel elutingimuste, ressursside ja akadeemilise tunnustuse pärast. Viimane analoogia hõimude kohta on võetud Tony Becheri ja Paul R. Trowleri (2001) klassikalisest teosest „Academic tribes and territories“ („Akadeemilised hõimud ja territooriumid“). Nende sõnul käsitletakse kehtivaid tavasid akadeemilistel territooriumidel nii, et spetsiifilisi „hõimuomadusi“ saaks distsipliinide sees eristada. Hõimu oluline tunnus on kogukonna- ja ühtekuuluvustunne, mida keskkond pakub. Becher ja Trowler väidavad, et teadmisi ei omandata üksnes ratsionaalsetel või epistemoloogilistel alustel, pigem mõjutab seda akadeemiliste kogukondade ja koolkondade sotsiaalne ülesehitus. Erinevad teaduslikud uurimisviisid kujunevad üldjoontes samamoodi kui hõimud ja kogukonnad. 
Seda vaatenurka teadmiste sotsiaalsete tingimuste kohta on tutvustanud ka Peter L. Berger ja Thomas Luckmann oma raamatus „The social construction of reality“ (1966). Ka prantsuse filosoofi Michel Foucault' (nt 1969) tutvustatud teadmiste genealoogia ja arheoloogia ideed annavad kasuliku ülevaate teadmiste sotsiaalsest ja ajaloolisest ülesehitusest. Foucault' genealoogilised ja arheoloogilised teadmiste analüüsid viitavad sellele, et teadmised omandatakse teadmiste, tõe ja võimu kohta käivate väljakujunenud arusaamade kaudu. Meie jaoks näiliselt loomulikud kategooriad on tegelikult ajaloolised konstruktsioonid, mida liigendavad sõnad ja diskursused. Erinevad akadeemilised koolkonnad ehk „hõimud“ toetavad samuti ajalooliselt teadmistele kohaldunud ühiskondlikke tingimusi ning moodustavad seega raamistiku pedagoogilise arengu mõistmiseks. Näiteks võime praegu näha majandussektori kehtestatud eelduste mõju haridussektorile. Nende majanduslikest väärtustest ja tootlikkuse tagaajamisest välja kasvanud neoliberaalsete eelduste kohaselt saab haridust muuta efektiivsemaks, pannes lapsed ja koolid üksteisega konkureerima (Peters \& Bulut, 2011).

Teadmiste sotsioloogilisi aspekte on kasulik teada, kui mõnd pedagoogilist või didaktilist uurimisviisi hakatakse kindla koolkonnaga seostama. Ühtlasi tasub mõelda uurimisviiside seostele mitmesuguste teadmisi loovate huvide või kalduvustega. Eri traditsioonidest ja teadmistest tulenevate huvide seoste kohta võib olla väga keeruline või üldse võimatu üldistusi teha, kuid mõningaid ühiseid omadusi on siiski võimalik leida.

Arendusuuring ning teadus- ja arendustegevus keskenduvad vähemalt oma algsel kujul küsimusele, mida võib mõista tehniliste ja tootmisalaste probleemidena: kuidas kujundada toodet või protsessi, mudelit või sotsiaalset tava, mis toimiks tõhusalt? Nende uurimisviiside korral tundub, et huvi rakendatud tavade sotsiaalsete või ajalooliste tingimuste vastu on väike või olematu, kuigi ökoloogilise aspektiga mõnel juhul siiski arvestatakse. Sama näib kehtivat ka translatiivsete uuringute kohta, kus tegeldakse enamasti uurimistulemuste n-ö tõlkimisega praktikutele ja vastupidi. Tegevusuuringud, tööviise arendavad uuringud ja praktikute teadusuuringud on mitmekülgsed uurimisviisid ning riskantne on väita midagi selle kohta, kuidas need on seotud teadmistel põhinevate huvidega. Siiski on arendustöö uuringuid seotud sotsiaalsete, kultuuriliste ja ajalooliste tegevuskohtadega. Selle suuna teoreetilised alused on välja töötanud Võgotski ja Leontjev ning seega võib seda seostada tõlgendusliku-praktilise suunaga. Tegevusuuringud ja praktikute teadusuuringud tunduvad aga pedagoogilise arendustöö jaoks väga laialivalguvad suunad. Mõne jaoks on tegevusuuringud kõige laiem suund, mis hõlmab ka praktikute teadusuuringuid, samal ajal kui teised on täiesti vastupidisel seisukohal. Vähemalt see on kindel, milline uurimisviis on kõige vanem: tegevusuuringud olid esimesed ja seega alustasid 
mängu. Sellest vaatenurgast lähtudes võib pidada ajaloo eitamiseks seda, kui ignoreeritakse tegevusuuringute osatähtsust ja alustatakse ajaloolist narratiivi praktikute teadusuuringutest, arendusuuringutest, arendustöö uuringutest, translatiivsetest uuringutest või muudest moodsatest kontseptsioonidest ning toetatakse uurimisviise, mis kuulutavad end „uueks“ ja „värskeks“, võib-olla ainult selleks, et jätta mulje uusimate moesuundumuste järgimisest.

Raske on öelda midagi üldistavat ka teadmisi loovate huvide kohta, mis on seotud tegevusuuringute või praktikute teadusuuringutega. Samas võib siinkohal jällegi abiks olla ajalooline perspektiiv. Habermas töötas välja oma teadmiste ja inimlike huvide teooria 1960. aastate lõpus ja see avaldati 1970. aastate alguses ehk palju hiljem, kui alustati tegevusuuringute tegemist. Seetõttu võib algsete tegevusuuringute kontekstis vähe öelda teadmistega seotud huvide kohta. Sama kehtib praktikute teadusuuringute kohta.

Sellegipoolest peab iga teadlane ise otsustama, kuidas nimetada oma uurimisviisi, mille eesmärk on täiustada pedagoogilisi tavasid. Mis iganes metodoloogilise uurimisviisi või akadeemilise hõimuga soovite end seostada, on teie põhiline epistemoloogiline orientatsioon väärt kajastamist. Kas asi on ainult teoorias: kas püüdlete puhaste teadmiste poole, mis tähendab, et järgite teoreetilist suunda hariduse kohta? Või olete pigem huvitatud haridusvaldkonna meetodite ja tavade täiustamisest? Kas küsimus on tõhusate vahendite loomises, et toetada õpetamist tehnilis-instrumentaalsest vaatenurgast? Või pooldate kontekstivälist lähenemist teemale ja võtate arvesse nii ajaloolisi, filosoofilisi, sotsiaalseid kui ka ökoloogilisi asjaolusid, samuti küsimusi hariduse eesmärkide ja väärtuste kohta, mille kaudu seostute tõlgendusliku-praktilise vaatenurgaga? Või tahate muuta maailma, selle asemel et seda vaid tõlgendada, mis tähendab, et pooldate kriitilis-emantsipatoorset suunda? Ainult teie saate neile küsimustele vastata - valik on ainuüksi teie teha. Seejuures ei vali te musta ega valge või hea ega halva vahel, vaid teete valiku oma teadlikkuse ning oma lugejate teavitamise ja valgustamise huvides.

\section{Kasutatud kirjandus}

Anderson, G. L., \& Herr, K. (1999). The new paradigm wars: Is there room for rigorous practitioner knowledge in schools and universities? Educational Researcher, 28(5), 12-21, 40. https://doi.org/10.3102/0013189X028005012

Aristotle (2011/350 BCE). Aristotle's Nicomachean ethics. Chicago: University of Chicago Press.

Becher, T., \& Trowler, P. R. (2001). Academic tribes and territories: Intellectual enquiry and the culture of disciplines (2nd ed.). London: Society for Research into Higher Education. 
Bereiter, C. (2002). Education and mind in the knowledge age. Mahwah: Lawrence Erlbaum.

Berger, P. L., \& Luckmann, T. (1966). The social construction of reality: A treatise in the sociology of knowledge. London: Penguin.

Broekkamp, H., \& van Hout-Wolters, B. (2007). The gap between educational research and practice: A literature review, symposium, and questionnaire. Educational Research and Evaluation, 13(3), 203-220. https://doi.org/10.1080/13803610701626127

Burns, D. (2007). Systemic action research: A strategy for whole system change. Exeter: Policy Press.

Candy, L. (2006). Practice-based research: A guide (CCS Report: 2006-V1.0 November). Sydney: University of Technology, Creativity \& Cognition Studios.

Carr, W., \& Kemmis, S. (1986). Becoming critical: Education, knowledge and action research. London: Falmer Pess.

De Jong, F., de Beus, M., Richardson, R., \& Ruijters, M. (2013). Ecologically and transdisciplinarily inspired research: Starting points for practitioner research and sustainable change. Journal of Organisational Transformation \& Social Change, 10(2), 163-117. https://doi.org/10.1179/1477963313Z.0000000008

Denzin, N., \& Lincoln, S. (Eds.) (2005). The SAGE handbook of qualitative research (3rd ed.). Thousand Oaks: Sage.

Dinkelman, T. (2003). Self-study in teacher education: A means and ends tool for promoting reflective teaching. Journal of Teacher Education, 54(1), 6-18. https://doi.org/10.1177/0022487102238654

Engeström, Y., \& Rückriem, G. (Eds.) (2005). Developmental work research: Expanding activity theory in practice (International cultural-historical human sciences No. 12). Berlin: Lehmanns Media.

Foucault, M. (1969). The archaeology of knowledge. London, New York: Routledge.

Habermas, J. (1972). Knowledge and human interests. Boston: Beacon Press.

Heikkinen, H. L. T., de Jong, F. P. C. M., \& Vanderlinde, R. (2016). What is (good) practitioner research? Vocations and Learning, 9(1), 1-19. https://doi.org/10.1007/s12186-016-9153-8

Heikkinen, H. L. T., \& Huttunen, R. (2017). 'Mitä järkeä?’: Kasvatuksen tietoperusta ja rationaalisuus. In A. Toom, M. Rautiainen, \& J. Tähtinen (toim.), Toiveet ja todellisuus: Kasvatus osallisuutta ja oppimista rakentamassa (Kasvatusalan tutkimuksia No. 75, pp. 31-58). Turku: Suomen kasvatustieteellinen seura.

Heikkinen, H. L. T., Huttunen, R., \& Syrjälä, L. (2007). Action research as narrative: Five principles for validation. Educational Action Research, 15(1), 5-19. https://doi.org/10.1080/09650790601150709

Heikkinen, H., Kiilakoski, T., Huttunen, R., Kaukko, M., \& Kemmis, S. (2018). Koulutustutkimuksen arkkitehtuurit. Kasvatus, 49(5), 368-383.

Kemmis, S. (2012). Researching educational praxis: Spectator and participant perspectives. British Educational Research Journal, 38(6), 885-905. https://doi.org/10.1080/01411926.2011.588316

Kemmis, S., \& Edwards-Groves, C. (2017). The nature and study of education: A primer of the theory of practice architectures. Singapore: Springer. 
Kemmis, S., \& McTaggart, R. (2000). Participatory action research: Communicative action and the public sphere. In N. Denzin \& Y. Lincoln (Eds.), Handbook of Qualitative Research (pp. 567-606). Thousand Oaks: Sage.

Kemmis, S., \& Smith, T. J. (2008a). Personal praxis: Learning through experience. In S. Kemmis \& T. J. Smith (Eds.), Enabling praxis: Challenges for education (pp. 15-35). Rotterdam: Sense Publishers.

Kemmis, S., \& Smith, T. J. (2008b). Praxis and praxis development: About this book. In S. Kemmis \& T. J. Smith (Eds.), Enabling praxis: Challenges for education (pp. 3-13). Rotterdam: Sense Publishers.

Loughran, J. J. (2004). Learning through self-study: The influence of purpose, participants and context. In J. J. Loughran, M. L. Hamilton, V. K. LaBoskey, \& T. L. Russell (Eds.), International handbook of self-study of teaching and teacher education practices (Kluwer international handbooks of education No. 12, pp. 151-192). Dordrecht: Kluwer Academic. https://doi.org/10.1007/978-1-4020-6545-3_5

Mahon, K., Heikkinen, H. L. T., \& Huttunen, R. (2019). Critical educational praxis in university ecosystems: Enablers and constraints. Pedagogy, Culture and Society, 27(3), 463-484. https://doi.org/10.1080/14681366.2018.1522663

Marshall, E. A. (2010). Practice-oriented research. In A. J. Mills, G. Durepos, \& E. Wiebe (Eds.), Encyclopedia of case study research (pp. 722-723). Thousand Oaks: Sage. https://doi.org/10.4135/9781412957397.n266

Niglas, K. (2004). The combined use of qualitative and quantitative methods in educational research (Doctoral dissertation). Tallinn: Tallinn Pedagogical University.

Peters, M., \& Bulut, E. (Eds.) (2011). Cognitive capitalism, education and digital labor. New York: Peter Lang.

Popper, K. R. (1963). Conjectures and refutations: The growth of scientific knowledge. London: Routledge \& Kegan Paul.

Reason, P., \& Bradbury, H. (Eds.) (2007). The SAGE handbook of action research: Participative inquiry and practice (2nd ed.). London: Sage.

Saugstad, T. (2005). Aristotle's contribution to scholastic and non-scholastic learning theories. Pedagogy, Culture and Society, 13(3), 347-366. https://doi.org/10.1080/14681360500200233

Tierney, W. M., Oppenheimer, C. C., Hudson, B. L., Benz, J., Finn, A., Hickner, J. M., Lanier, D., \& Gaylin, D. S. (2007). A national survey of primary care practicebased research networks. The Annals of Family Medicine, 5(3), 242-250. https://doi.org/10.1370/afm.699

Van den Akker, J., Gravemeijer, K., McKenney, S., \& Nieveen, N. (2006). Educational design research. London: Routledge.

Vanderlinde, R., \& van Braak, J. (2010). The gap between educational research and practice: Views of teachers, school leaders, intermediaries and researchers. British Educational Research Journal, 36(2), 299-316. https://doi.org/10.1080/01411920902919257

Välimaa, J., Heikkinen, H. L. T., \& Arvaja, M. (2018). Koulutuksen tutkimuksen ääni. Kasvatus, 49(5), 363-367. 